\title{
APLIKASI TEKNOLOGI PENGOLAHAN AIR ASIN DESA TARUPA KECAMATAN TAKA BONERATE KABUPATEN SELAYAR
}

\author{
Oleh : \\ Wahyu Widayat \\ Pusat Teknologi Lingkungan, Badan Pengkajian dan Penerapan Teknologi (BPPT)
}

\begin{abstract}
Takabonerate is one of the 23 regencies in South Sulawesi where it is locates at the southern parth of South Sulawesi Province and it is surrounded by flores sea. As maritime regency, its mainland is $1,188.28 \mathrm{~km}^{2}$ (5.23\%) and the sea is approximately $21,138.41 \mathrm{~km}^{2}(94.68 \%)$. It has 126 islands wich consist of small and big islands. Tarupa village's a subdistrict located in a tidy and peat area. The community living in tarupa use surface water of river as the main clean water resource. The surface water is influenced by the tide of sea water. The surface water taste is very salty (TDS>12000ppm). The use of rain water as the second alternative is very limited, i.e it is only in rainy season.

To deal with the chronic problem, such as the lack of clean water supply, it needs an appropriate water treatment technology. The suitable water treatment system is a combination of conventional and advanced technology. Desalination, such as Reverse Osmosis must be involved to reduce salinity of the raw water. A complete process includes the pretreatment and advance treatment. The pretreatment are oxidation and some common filtrations. The advance treatment is a molecular filtration using a membran which the principal is reverse osmosis pressure. If the pilot water treatment plant is avalaible in Tarupa in Takabonerate, the clean water supply will not be a serious problem. Generally, it can also play an important role to increase the social level of community in South Sulawesi..
\end{abstract}

Kata Kunci : Teknologi, pengolahan, air asin, reverse osmosis, air minum.

\section{PENDAHULUAN}

Pulau selayar adalah merupakan salah satu kabupaten diantara 23 kabupaten/ kota di Propinsi Sulawesi Selatan. Pulau terletak diujung selatan Propinsi Sulawesi Selatan dikelilingi oleh laut Flores di sebelah Timur dan Selatan, Selat Makasar dan Laut Flores di sebelah Barat dan Teluk Bone Kabupaten Selayar, dan sebelah utara kota Makasar.

Selayar Sebagai kabupeten maritim memiliki wilayah daratan seluas $\pm 1.188,28 \mathrm{~km}^{2}$ $(5,23 \%)$ wilayah laut $\pm 21.138,41 \mathrm{~km}^{2} \quad(94,68 \%)$, jumlah pulau-pulau besar dan kecil sebanyak \pm 126 buah, secara umum mempunyai permasalahan pengadaan air tawar, dimana pemenuhan air bersih (tawar) pada umumnya mengandalkan air hujan atau mengambil dari daerah lain.

Desa Tambuna terletak di salah satu pulau di kecamatan Taka Bonerate, Kabupaten Selayar (lihat gambar 16), yang berpenduduk sekitar 2.000 jiwa, tergolong desa tertinggal. Daerah ini sangat datar dan hanya mempunyai perbedaan ketinggian sangat kecil dengan permukaan laut, sehingga daerah ini didominasi rawa-rawa dan sangat terpengaruh pasang surut air laut. Sumber air utama penduduk Tambuna pada waktu musim penghujan adalah menampung air hujan dan pada waktu musim kemarau kebutuhan air dipenuhi dari daerah lain yang diangkut dengan kapal-kapal nelayan.

Upaya yang telah dilakukan oleh Pemerintah Daerah setempat terhambat oleh keterbatasan dana dan kualitas sumberdaya manusia. Suplai air bersih ke lokasi mengalami banyak hambatan, misalnya cuaca dan waktu tempuh yang lama karena hanya dapat ditempuh dengan jalur laut.

Pada kondisi kemarau panjang dan adanya intrusi air laut, kualitas air tanah dangkal menurun, sehingga air menjadi asin karena tingginya kadar garam. Pada kondisi semacam ini kadar garam (Total Disssolved Solid) mencapai lebih dari 12.000 ppm. Oleh karena itu wilayah tersebut sangat memerlukan instalasi pengolahan air (IPA) yang mampu untuk mengolah air asin menjadi air tawar.

Salah satu cara yang memungkinkan untuk pemenuhan air bersih, kususnya air minum adalah pembangunan unit Instalasi Pengolahan Air yang sesuai dengan kondisi air baku. Berdasarkan data kualitas air baku, proses yang harus diterapkan meliputi oksidasi, filtrasi dan desalinasi air asin dengan sistem Reverse Osmosis (Osmosa Balik). Instalasi pengolahan 
air asin dengan sistem reverse osmosis dirancang sesuai dengan tingkat sosial ekonomi serta kebutuhan air minum masyarakat setempat.

\section{PERMASALAHAN DAN TUJUAN}

Kualitas air tanah dangkal di kecamatan Taka Bonerate, khsusnya desa Tambuna sudah tercemar karena tingginya kadar garam, sehingga tidak memenuhi syarat lagi untuk digunakan sebagai air minum. Ketersediaan air tanah dangkal rata-rata hanya ada pada saat musim penghujan dan pada musim kemarau panjang air tawar tanah dangkal menipis sehingga tidak mampu lagi memenuhi kebutuhan air tawar, sedangkan penampungan air hujan (PAH) kuantitasnya sangat terbatas, sehingga untuk memenuhi kebutuhan air minum mendatangkan dari daerah terdekat (kota kecamatan Taka Bonerate) yang masih ada sumber air tawar, dengan harga yang relatif mahal yang ditempuh 2 jam perjalanan melewati jalur laut

Seiring dengan pertambahan penduduk di desa Tmbuna dan meningkatnya harga BBM ditambah lagi dengan musim kemarau panjang, kebutuhan air minum sangat sulit dipenuhi. Kualitas air tanah dangkal semakin menurun, disebabkan oleh intrusi air laut, dimana air menjadi asin karena tingginya kadar garam, dan untuk menyajikan air minum yang sehat harus dibayar dengan harga yang mahal akibat melambungnya harga BBM. Dalam kondisi semacam ini sangat diperlukan instalasi pengolahan air yang mampu mengolah air asin menjadi air tawar dan siap minum.

\section{TUJUAN}

Dalam tulisan ini diuraikan salah satu cara mengatasi masalah pemenuhan air bersih (siap minum) di desa Tambuna, kecamatan Taka Bonerate, Kabupaten Selayar dengan mengaplikasikan teknologi pengolahan air asin dengan sistem Reverse Osmosis

\section{METODOLOGI}

\subsection{Survei Lokasi}

Survai lokasi dilakukan untuk mengetahui kualitas air baku, jumlah penduduk yang akan dilayani, kondisi sosial \& ekonomi masyarakatnya.

\subsection{Sampling Air Baku}

Pengambilan sampel dan analiasa air baku dilakukan pada beberapa titik untuk mendapatkan data kualitas air yang dapat mewakili kualitas air baku

\subsection{Penentuan Lokasi}

Aplikasi pengolahan air asin dengan sistem reverse osmosis di desa Tarupa ditentukan dengan pertimbangan segi teknis pembangunan, pengoperasian dan distribusi, dimana linstalasi Pengolahan Air (IPA) ditempatkan pada jarak terdekat dengan pemukiman dan sumber air yang akan diolah

\subsection{Ketersediaan bahan dan Peralatan}

Bahan dan peralatan yang digunakan untuk membangun IPA dipilih dengan pertimbangan untuk mempermudah penyediaan suku cadang dan biaya kontruksi maupun operasionalnya murah.

\subsection{Disain}

Data kualitas air baku digunakan untuk menentukan disain proses yang akan digunakan, yaitu sebagai acuan penentuan jumlah bahan-bahan kimia, sistem pengolahan pendahuluan yang akan digunakan, sistem pengolahan lanjutan untuk air asin

\subsection{Aplikasi}

Aplikasi pengolahan air asin menjadi air tawar siap minum diawali dengan pembangunan bangunan pelindung peralatan, kemudian installing pembangkit listrik dan konstruksi unit proses dalam Sistem IPA.

\subsection{Pelatihan Sumberdaya Manusia}

Masyarakat setempat harus mampu mengelola Instalasi Pengolahan Air tersebut, yaitu mampu mengoperasikan, mensosialisasikan hasil pengelolaan IPA. Untuk itu sebelum diserahkan kepada masyarakat untuk dikelola, dilakukan pelatihan pengoperasian dan perawatan Instalasi Pengolahan Air tersebut.

\section{DESALINASI}

Pemisahan air tawar dari air asin lazim disebut Desalinasi. Ada beberapa cara desalinasi, yaitu; distilasi, pembekuan, membran, penguapan dan penukar ion (Gambar 1). Aplikasi desalinasi yang telah banyak dipakai antara lain, distilasi (penguapan), filtrasi (membran) dan pertukaran ion. 
Ada tiga cara desalinasi dengan Distilasi yaitu : multi stage flash distillation, multiple effect distillation dan vapor compression distillation, sedangkan proses membran dibagi menjadi dua yaitu: Reverse osmosis (Osmosa Balik) dan Electrodialysis.

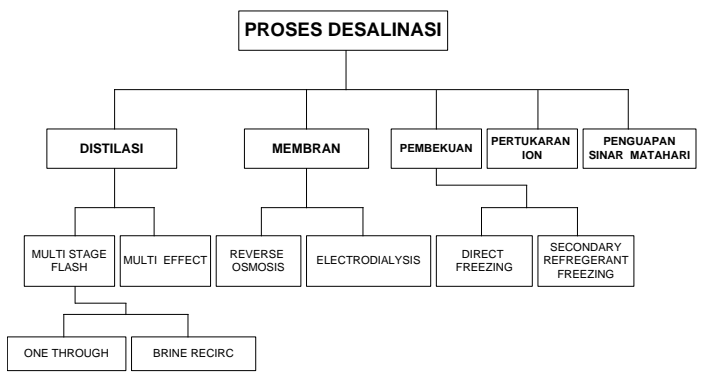

Gambar 1 : Penggolongan Proses Desalinasi

Dari berbagai cara desalinasi, aplikasi yang paling banyak adalah desalinasi dengan cara distilasi, selanjutnya disusul oleh teknologi membrann osmosis balik dan seterusnya. (Tabel $1)$.

Tabel 1: Aplikasi jenis proses \& kapasitas desalinasi.

\begin{tabular}{|l|r|r|}
\hline \multicolumn{1}{|c|}{ Jenis Proses } & $\begin{array}{c}\text { Kapasitas } \\
\left(\mathrm{m}^{3} / \text { hari }\right)\end{array}$ & $\begin{array}{c}\text { Prosentase } \\
(\%)\end{array}$ \\
\hline $\begin{array}{l}\text { Distilasi } \\
\text { (MSF+ME+VC) }\end{array}$ & 11.084 .908 & 59,2 \\
\hline Osmosis Balik & 6.109 .244 & 32,7 \\
\hline Elektrodialisa & 1.070 .005 & 5,7 \\
\hline Lain-lain & 446.110 & 2,4 \\
\hline Total & 18.710 .267 & 100,0 \\
\hline
\end{tabular}

Sumber : "Worldwide Desalting Plants Inventory Reports" yang diterbitkan oleh International Desalination Assosiation (IDA); Mei 1994,

Dari tabel di atas dapat dilihat bahwa teknologi desalinasi yang banyak digunakan saat ini adalah proses distilasi dan reverse osmosis.

\section{$5.1 \quad$ Distilasi}

Pada sistem distilasi, air asin yang digunakan sebagai bahan baku jumlahnya 10 kali dari air tawar yang akan dihasilkan. Media pemanas menggunakan steam dari boiler atau sumber lainnya. Perbandingan jumlah produksi air tawar terhadap jumlah panas steam yang diperlukan disebut Performance Ratio atau Gained Output Ratio (GOR). Rancangan biasanya memakai performance ratio 6 sampai 8, jadi steam pemanas yang dibutuhkan jumlahnya 1/6 sampai $1 / 8$ dari air yang dihasilkan.

Kerak dan karat pada peralatan adalah masalah yang biasa timbul pada semua jenis sistem distilasisi. Apabila terjadi kerak pada tube penukar panas evaporator maka panas penguapan akan menurun, suhu pemanas meningkat sehingga efisiensi panas dan produksi air tawar akan berkurang (Gambar 2). Dalam kondisi ini desalinasi harus diberhentikan untuk pembersihan tube dengan asam. Penerapan desalinasi yang efektif sangat diperlukan.

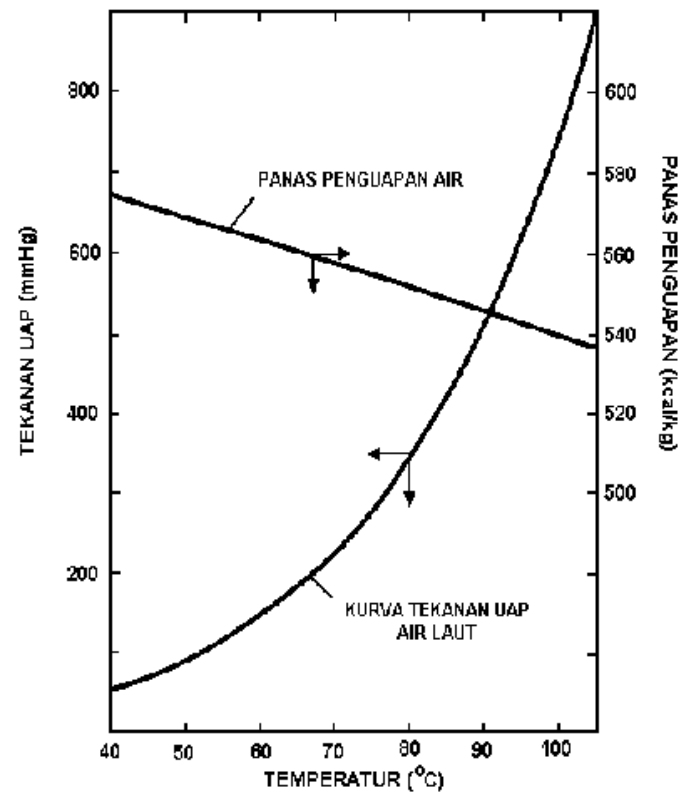

Gambar 2 :Kurva tekanan uap air laut dengan konsentrasi garam 3,5\% dan panas penguapan.

\subsection{Reverse Osmosis}

\subsection{Membran Reverse Osmosis}

Modul membran reverse osmosis (Gambar 3) untuk mengolah air dibagi menjadi tiga, yaitu membran air tawar, membran air payau dan membran air asin/laut. Masing masing jenis membran tersebut mempunyai karakteristik yang berbeda, baik operasionalnya yang ditentukan dengan tekanan operasi maupun kemampuan dalam menahan partikel garam. Membran air tawar mampu mengolah air dengan kandungan TDS sampai 500 ppm dengan tekanan operasi sampai $5 \mathrm{~kg} / \mathrm{cm}^{2}$, membran air payau mampu mengolah air dengan kandungan TDS sampai 12.000 ppm dengan tekanan operasi sampai 10 $\mathrm{kg} / \mathrm{cm}$ dan membran air asin/laut mampu mengolah air dengan kandungan TDS sampai 40.000 ppm dengan tekanan operasi sampai 50 $\mathrm{kg} / \mathrm{cm}$.

Kapasitas olah membran ditentukan oleh luas permukaan modul membran, yaitu dengan variabel dimensi membran (diameter dan panjang) maupun jumlah modul membran yang digunakan dengan penyusunan seri, paralel maupun kombinasi seri paralel. Salah satu 
contoh pemasangan modul membran dapat dilihat pada Gambar 4.

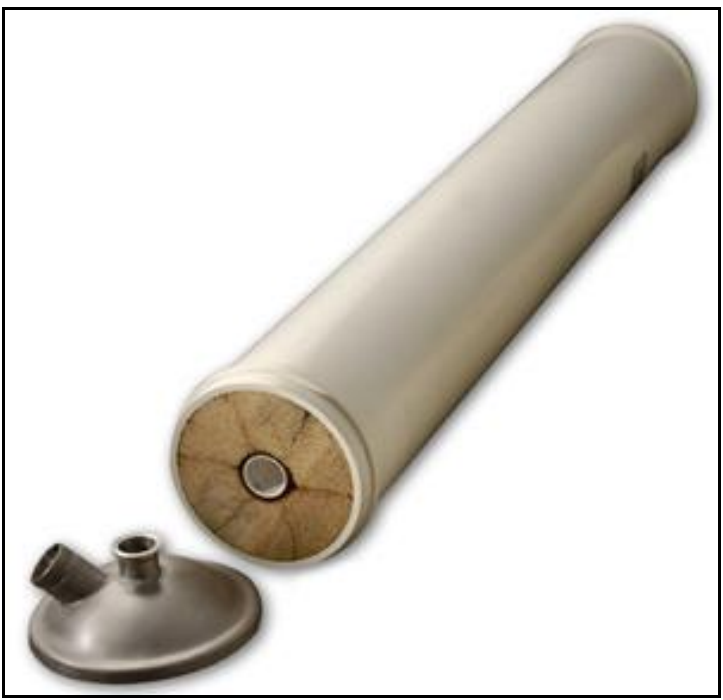

Gambar 3 : Modul membran reverse osmosis.

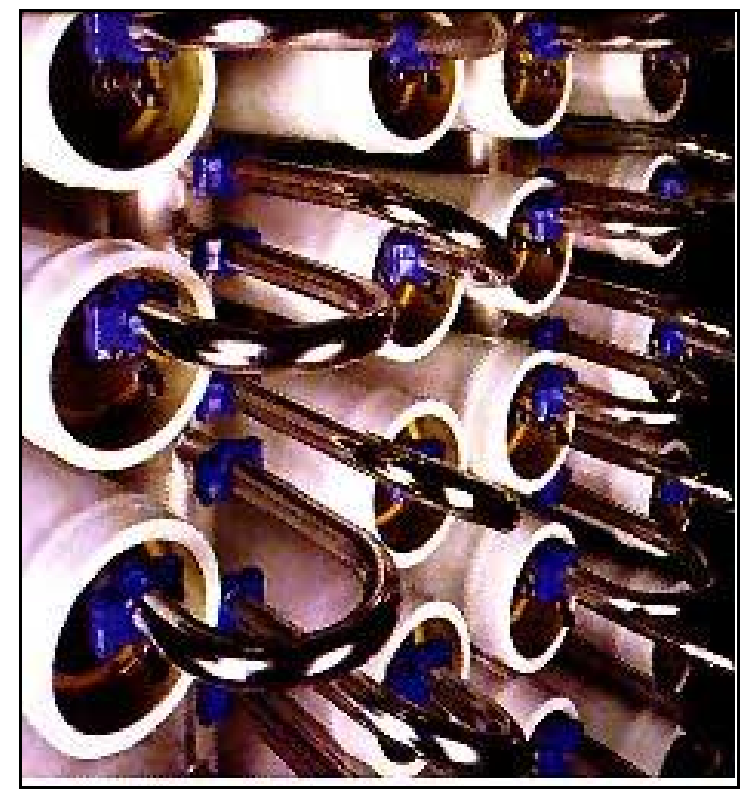

Gambar 4 : Susunan beberapa modul membrane dengan kombinasi seri paralel.

\subsection{Prinsip reverse osmosis}

Prinsip dasar pengolahan air asin dengan membran reverse osmosis ditunjukkan seperti Gambar 5. Pada prinsipnya apabila dua buah larutan dengan konsentrasi encer dan pekat dipisahkan oleh membran semi permeabel, maka larutan dengan konsentrasi yang encer akan terdifusi melalui membran semi permeabel tersebut dan masuk ke dalam larutan yang pekat sampai terjadi kesetimbangan konsentrasi. Fenomena tersebut disebut proses osmosis. Prinsip dasar proses osmosa dan proses osmosa balik tersebut ditunjukkan seperti pada Gambar 6.

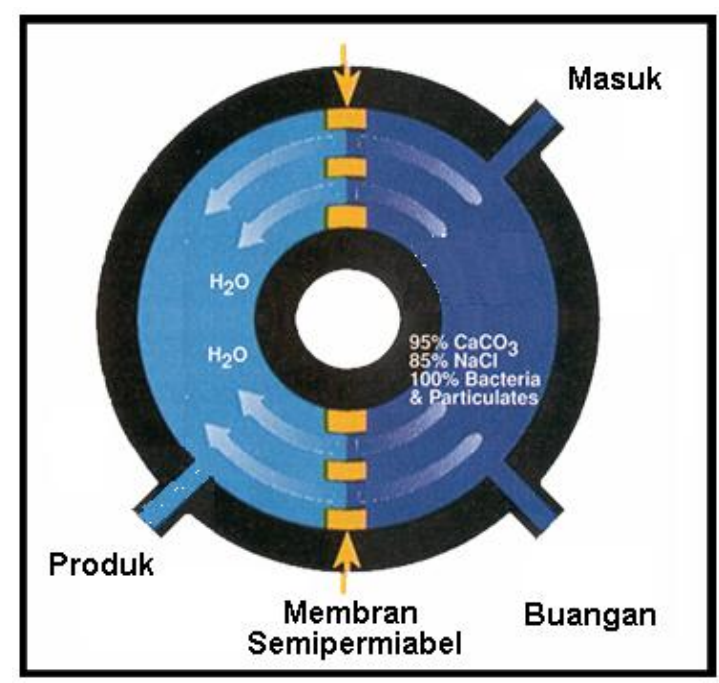

Gambar 5 : Prinsip desalinasi dengan membran.
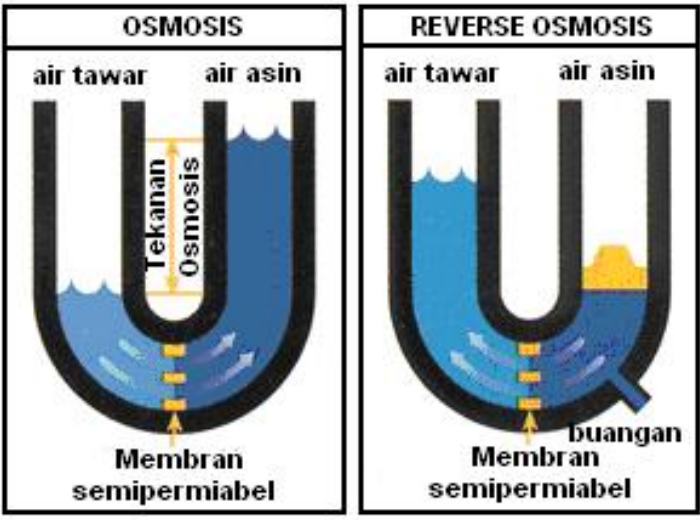

Gambar 6 : Prinsip dasar osmosis \& reverse osmosis .

Dalam pengolahan air asin, air tawar sebagai larutan dengan konsentrasi encer dan air asin disebut dengan larutan dengan konsentrasi pekat dipisahkan dengan membran semi permeabel, maka air tawar akan terdifusi ke dalam air asin melalui membran semi permeabel tersebut, sehingga terjadi kesetimbangan. Apabila diberikan tekanan yang lebih besar dari tekanan osmosisnya, maka aliran air tawar akan berbalik yakni dari air asin ke air tawar melalui membran semi permeabel, sedangkan garamnya tertahan di dalam larutan garammya sehingga menjadi lebih pekat. Proses tersebut dikenal dengan proses Reverse Osmosis (osmosa balik).

Daya yang menyebabkan terjadinya difusi air tawar ke dalam air asin melalui membran semi permeabel dinamakan tekanan osmosis. Tekanan osmosis dipengaruhi karakteristik jenis membran, temperatur air, dan konsentrasi garam (salinitas) serta senyawa lain yang terlarut dalam 
air (TDS). Air asin mengandung TDS \pm 12.000 ppm atau lebih pada suhu $25^{\circ} \mathrm{C}$, mempunyai tekanan osmotik normal $\pm 6,9 \mathrm{~kg} / \mathrm{cm}^{2}$, Air laut yang mengandung TDS $\pm 35.000 \mathrm{ppm}$ pada suhu $25^{\circ} \mathrm{C}$ mempunyai tekanan osmotik normal $\pm 26,7$ $\mathrm{kg} / \mathrm{cm}^{2}$, dan untuk air laut di daerah timur tengah atau laut Merah kandungan garam lebih pekat dengan TDS $\pm 42,000 \mathrm{ppm}$, pada suhu $30^{\circ} \mathrm{C}$, tekanan osmosis $\pm 32,7 \mathrm{~kg} / \mathrm{m}^{2}$.

\subsection{Desalinasi Membran Reverse Osmosis}

Efisiensi proses desalinasi air asin dengan sistem Reverse Osmosis (osmosa balik) cukup tinggi $\pm 99,5 \%$. Seperti ditunjukkan pada Gambar 7, dalam proses Reverse Osmosis ini, air baku (air asin) dipompa dengan tekanan tinggi melampaui tekanan osmosisnya ke dalam suatu modul membran osmosa balik yang mempunyai dua buah pipa keluaran, yakni pipa keluaran untuk air tawar yang dihasilkan (product) dan pipa keluaran untuk air garam yang telah dipekatkan (reject/drain).

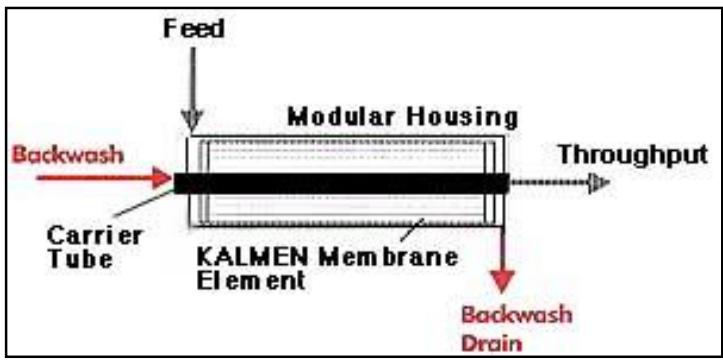

Gambar 7 : Proses pengolahan air asin dengan teknologi membran.

Di dalam proses penyaringan dengan ukuran molekul melalui membran reverse osmosis partikel yang molekulnya lebih besar dari pada molekul air, seperti molekul garam dan lainnya, akan terpisah dan akan ikut ke dalam air buangan, sehingga untuk menjaga membran dari kebuntuan, air yang akan masuk ke dalam membran reverse osmosis harus mempunyai persyaratan tertentu, misalnya kekeruhan harus nol, kadar besi dan mangan harus $<0,1 \mathrm{mg} / \mathrm{l}, \mathrm{pH}$ netral dan harus selalu dikontrol agar tidak terjadi pengerakan kalsium karbonat dan lainnya.

Tabel 2 : Standar Kualitas air baku untuk air umpan unit reverse osmosis.

\begin{tabular}{|c|l|c|c|}
\hline No & Parameter & Satuan & $\begin{array}{c}\text { Air Baku } \\
\text { (Max) }\end{array}$ \\
\hline 1 & Warna & Pt. Co Scale & 100 \\
\hline 2 & Bau & - & Relatif \\
\hline 3 & Kekeruhan & NTU & 20 \\
\hline
\end{tabular}

\begin{tabular}{|c|l|c|c|}
\hline 4 & Besi & $\mathrm{mg} /$ liter & 2,0 \\
\hline 5 & Mangan & $\mathrm{mg} /$ liter & 1,3 \\
\hline 6 & Khlorida & $\mathrm{mg} /$ liter & 4.000 \\
\hline 7 & Bahan Organik & $\mathrm{mg} /$ liter & 40 \\
\hline 8 & TDS & $\mathrm{mg} /$ liter & 12.000 \\
\hline
\end{tabular}

Pengolahan air payau dengan menggunakan sistem reverse osmosis ini sangat dipengaruhi oleh kualitas air baku yang akan diolah, apabila air baku tidak memenuhi persyaratan sebagai air baku reverse osmosis (Tabel 2), maka Instalasi Pengolahan Air dilengkapi dengan unit pengolahan awal (Pretreatment) dan setelah air baku memenuhi persyaratan dilanjutkan pada unit pengolahan lanjutan (Treatment), yaitu unitreverse osmosis. Air baku yakni air asin, terutama yang dekat dengan pantai pada umumnya masih mengandung partikel padatan tersuspensi, mineral, plankton dan lainnya, maka air baku tersebut perlu dilakukan pengolahan awal sebelum diproses di dalam unit osmosa balik.

Pengolahan pendahuluan terdiri dari pompa air baku tekanan operasi 4 Bar, pompa dosing tekanan operasi 7 Bar yang dilengkapi dengan tangki kimia, tangki reaktor, saringan pasir cepat, saringan mangan zeolit, dan saringan karbon aktif untuk penghilangan warna dan filter cartridge ukuran 0,5 $\mu \mathrm{m}$. Unit pengolahan lanjutan terdiri dari pompa tekanan tinggi, membran osmosis balik, pompa dosing bahan anti kerak (anti scalant) dan anti jamur (anti biofoaling) yang dilengkapi dengan tangki kimia dan sterilisator ultra violet (UV).

\section{PROSES PENGOLAHAN}

Proses pengolahan air asin dengan sistem reverse osmosis ini terbagi dalam 2 unit proses yaitu pengolahan pendahuluan untuk memenuhi standar kualitas air baku yang akan diolah pada unit reverse osmosis dan pengolahan lanjut untuk penghilangan garam, flow diagram dapat dilihat pada gambar 15 dan penerapannya dapat dilihat pada gambar 17-18.

\subsection{Pengolahan Pendahuluan}

Berdasarkan data kualitas air baku, diperlukan pengolahan pendahuluan atau yang disebut dengan pretreatment terdiri dari beberapa unit proses, yaitu oksidasi dan filtrasi. Proses oksidasi menggunakan bahan oksidator $\mathrm{KMnO}_{4}$ sedangkan proses filtrasi menggunakan saringan pasir cepat, saringan mangan zeolit, saringan karbon aktif dan cartridge filter.

Untuk mendapatkan air minum (tawar) 10.000 liter/hari, diperlukan sistem pengolahan pendahuluan dengan kapasitas tiga kali lipat kapasitas unit pengolahan lanjutan, yaitu sebesar 
\pm 30.000 liter per hari. Komponen dan spesifikasi unit pengolahan pendahuluan dapat dilihat pada Tabel 5.

\section{A. Oksidasi $\mathrm{KMnO}_{4}$}

$\mathrm{KMnO}_{4}$ digunakan sebagai bahan oksidator dengan tujuan untuk mengoksidasi besi dan mangan atau logam-logam valensi dua lainnya. Pembubuhan $\mathrm{KMnO}_{4}$ selain untuk oksidator juga sebagai bahan regenerasi media filter mangan zeolit (greensand).

Pompa dosing kapasitas maksimun sekitar 4,7 liter per jam cukup untuk menginjeksi $\mathrm{KMnO}_{4}$. Laju injeksi dapat diatur dengan cara mengatur jumlah stroke pompa dosing. Konsentrasi $\mathrm{KMnO}_{4}$ yang masuk ke static mixer dan tangki reaktor diatur kira-kira 0,3 ppm. Skema injeksi larutan kalium permanganat dapat dilihat pada Gambar 8.

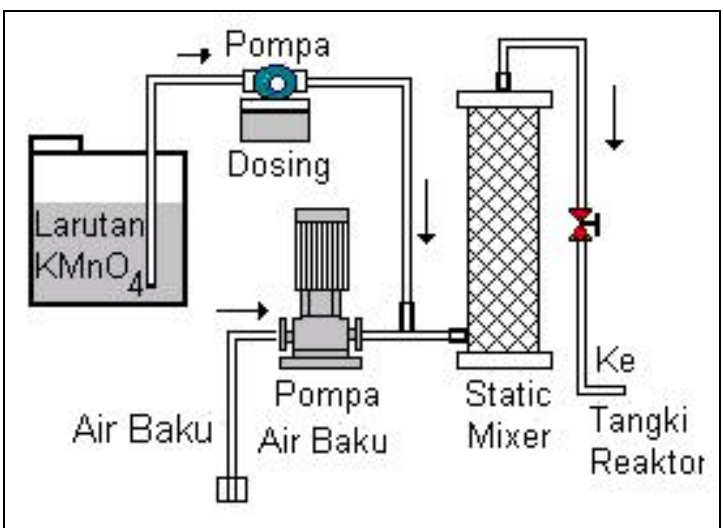

Gambar 8 : Skema injeksi larutan $\mathrm{KMnO}_{4}$.

\section{B. Saringan Pasir Cepat}

Padatan yang ada di dalam air serta oksida besi dan mangan yang terbentuk di dalam tangki reaktor tertahan di saringan pasir cepat. Media saringan pasir cepat terdiri dari batu kerikil kasar, kerikil halus, pasir kuarsa/silika kasar dan pasir silika halus, dengan susunan dari bawah ke atas adalah sebagai berikut :

- Kerikil kasar

$$
=5-10
$$

$\mathrm{Cm}$

- Kerikil halus

$$
=5-10
$$

$\mathrm{Cm}$

- Pasir silika kasar

$=30$

$\mathrm{Cm}$

- Pasir silika halus

$=50$

$\mathrm{Cm}$

Skema susunan media dalam saringan pasir cepat ditunjukkan pada Gambar 9. Dan cara pengoperasiannya ditunjukkan pada Gambar 10.

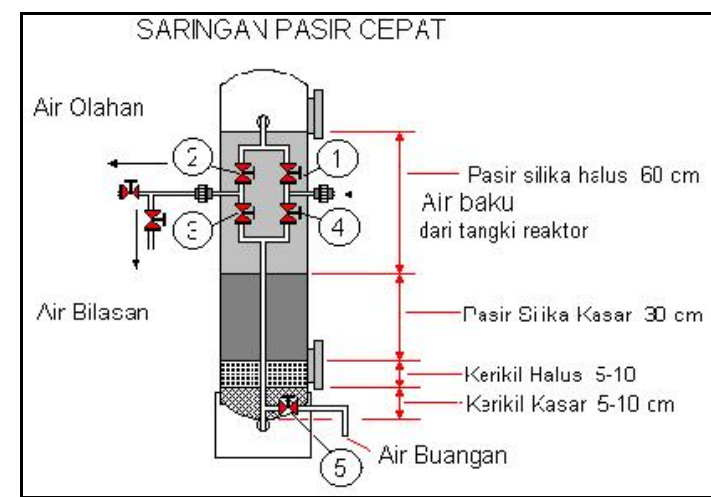

Gambar 9 : Susunan media saringan pasir.

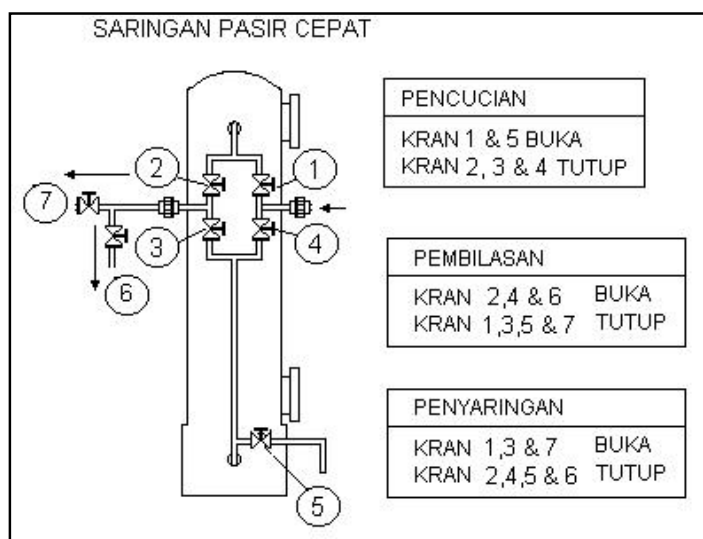

Gambar10 :Diagram pengoperasian saringan pasir.

\section{Saringan Mangan Zeolit}

Mangan Zeolit berfungsi sebagai katalis dan pada waktu yang bersamaan besi dan mangan yang ada dalam air teroksidasi menjadi bentuk ferri-oksida dan mangandioksida yang tak larut dalam air.

Reaksi :

$\mathrm{K}_{2} \mathrm{Z} \cdot \mathrm{MnO} \cdot \mathrm{Mn}_{2} \mathrm{O}_{7}+4 \mathrm{Fe}\left(\mathrm{HCO}_{3}\right)_{2}==>\mathrm{K}_{2} \mathrm{Z}+$

$$
3 \mathrm{MnO}_{2}+2 \mathrm{Fe}_{2} \mathrm{O}_{3}+8 \mathrm{CO}_{2}+4 \mathrm{H}_{2} \mathrm{O}
$$

$\mathrm{K}_{2} \mathrm{Z} \cdot \mathrm{MnO} \cdot \mathrm{Mn}_{2} \mathrm{O}_{7}+2 \mathrm{Mn}\left(\mathrm{HCO}_{3}\right)_{2}==>\mathrm{K}_{2} \mathrm{Z}+$ $5 \mathrm{MnO}_{2}+4 \mathrm{CO}_{2}+2 \mathrm{H}_{2} \mathrm{O}$

Reaksi penghilangan besi dan mangan dengan mangan zeoilte merupakan reaksi dari $\mathrm{Fe}^{2+}$ dan $\mathrm{Mn}^{2+}$ dengan oksida mangan tinggi (higher mangan oxide). Filtrat yang terjadi mengandung ferri-oksida dan mangan-dioksida yang tak larut dalam air dapat dipisahkan dengan pengendapan dan penyaringan. Selama proses berlangsung kemampunan reaksinya makin lama makin berkurang dan akhirnya menjadi jenuh. Untuk regenerasinya dapat dilakukan dengan menambahkan larutan $\mathrm{KMnO}_{4}$ ke dalam mangan zeolite yang telah jenuh tersebut sehingga akan terbentuk lagi mangan zeolite $\left(\mathrm{K}_{2} \mathrm{Z} \cdot \mathrm{MnO} \cdot \mathrm{Mn}_{2} \mathrm{O}_{7}\right)$. 
Media terdiri dari batu kerikil kasar, kerikil halus, pasir silika kasar, pasir silika halus dan mangan zeolit. Susunan media ditunjukkan pada Gambar 11 dan cara pengoperasian ditunjukkan pada Gambar 12. Susunan media dari bawah ke atas adalah sebagai berikut :

- Kerikil kasar

$=5-10 \quad \mathrm{Cm}$

- Kerikil halus

$=5-10$

$\mathrm{Cm}$

- Pasir silika kasar

$=10$

$\mathrm{Cm}$

- Pasir silika halus

$=20$

$\mathrm{Cm}$

- Manganese Zeolit

$\mathrm{Cm}$

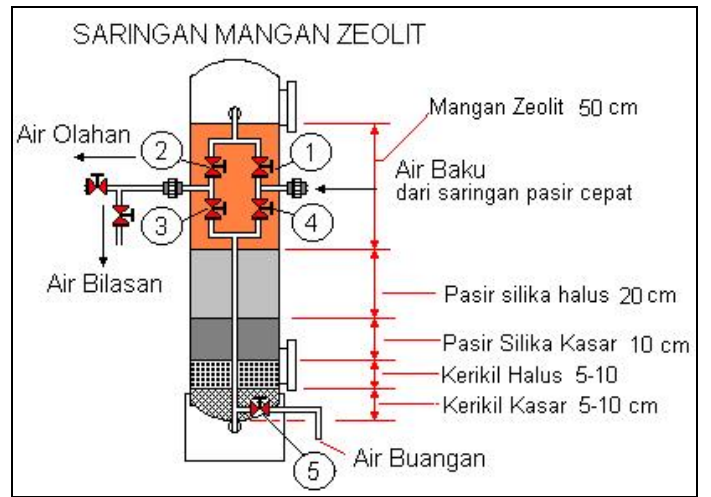

Gambar 11 : Susunan Media saringan Mangan Zeolit.

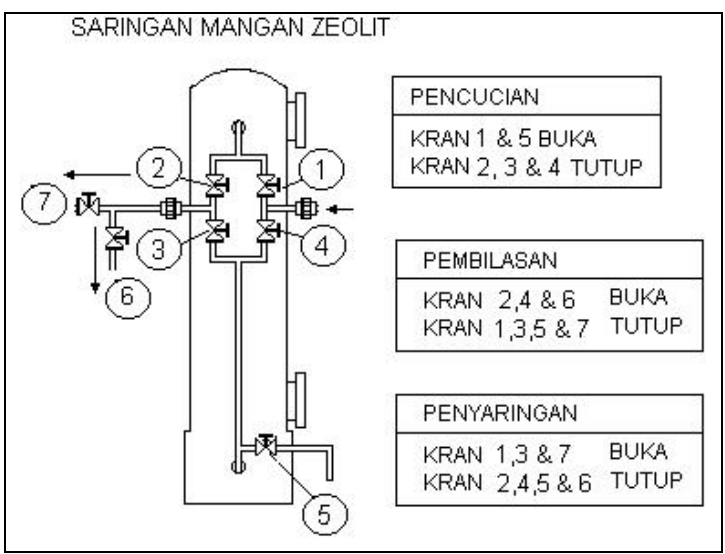

Gambar 12 : Diagram proses pengoperasian saringan Mangan Zeolit

\section{Saringan Karbon Aktif}

Saringan karbon aktif berfungsi untuk menghilangkan polutan mikro misalnya zat organik, deterjen, bau, senyawa phenol serta untuk menyerap logam berat dan lain-lain. Apabila seluruh permukaan karbon aktif sudah jenuh, maka proses penyerapan akan berhenti, dan pada saat ini karbon aktif harus diganti dengan karbon aktif yang baru.

Skema susunan media ditunjukkan pada Gambar 13, sedangkan skema proses pengoperasian filter karbon aktif ditunjukkan seperti pada Gambar 14. Susunan media dari bawah ke atas adalah sebagai berikut :
- Kerikil kasar

- Kerikil halus

- Pasir silika kasar

- Pasir silika halus

- Karbon aktif

$\begin{array}{rrr}= & 5-10 & \mathrm{Cm} \\ = & 5-10 & \mathrm{Cm} \\ = & 10 & \mathrm{Cm} \\ = & 10 & \mathrm{Cm} \\ = & 60 & \mathrm{Cm}\end{array}$

SARINGAN KARBON AKTIF

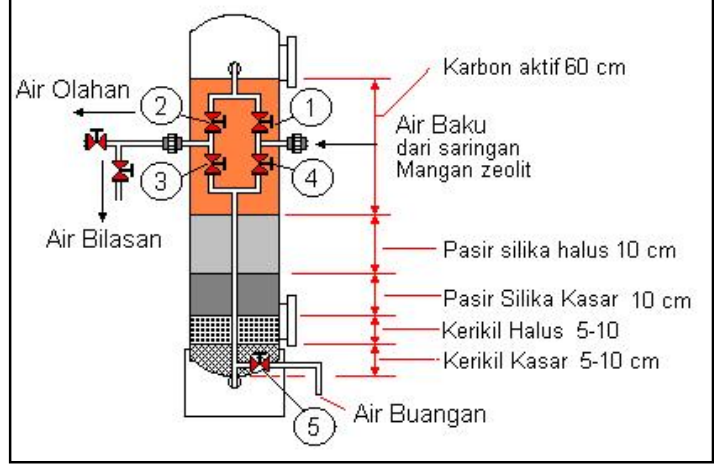

Gambar 13 : Susunan Media dalam saringan Karbon Aktif.

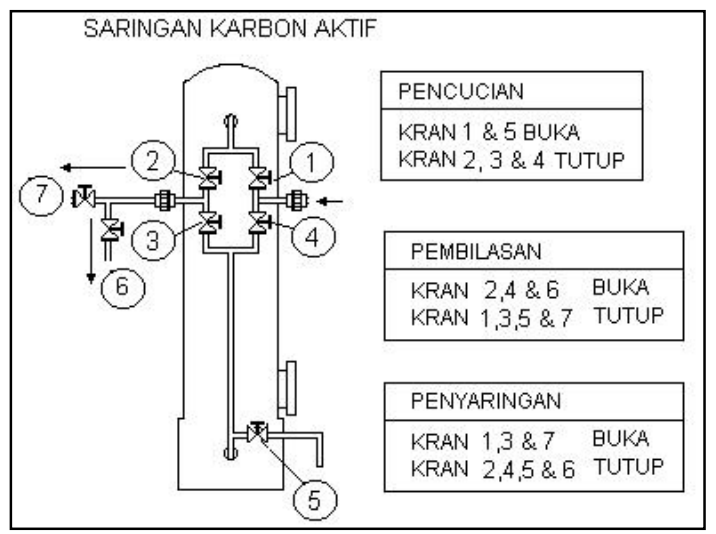

Gambar 14 : Diagram proses pengoperasian saringan Karbon Aktif.

\section{E. Cartridge Filter}

Unit proses dilengkapi dengan cartridge filter dengan ukuran $0,1 \mu \mathrm{m}$, sehingga secara keseluruhan produk air dari unit pengolahan pendahuluan ini diharapkan mempunyai kualitas yang dipersyaratkan seperti tabel-2 yaitu, kekeruhan < 5 NTU, Fe, $\mathrm{Mn}<0,1$ ppm dan Chlorida juga $<0,01$ ppm.

Unit pengolahan pendahuluan di atas belum dapat menghilangkan kadar garam, sehingga diperlukan pengolahan lanjutan untuk penghilangan garamnya (desalinasi)

\subsection{Pengolahan Lanjutan}

Yaitu proses penyaringan dengan menggunakan membran. Untuk menghasilkan air tawar, air asin yang telah memenuhi persyaratan sebagai air baku dipompa dengan tekanan tinggi ke dalam suatu modul membran reverse 
osmosis. Komponen dan spesifikasi unit pengolahan lanjutan dapat dilihat pada tabel 6 .

Efisiensi penghilangan garam dengan proses reverse osmosis ini mencapai 99,5\%. Modul membran osmosa balik mempunyai dua buah pipa keluaran, yakni pipa keluaran untuk air tawar sebagai produk dan pipa keluaran untuk air garam yang telah dipekatkan sebagai buangan. Di dalam membran reverse osmosis terjadi proses penyaringan dengan skala molekul, yaitu partikel yang molekulnya lebih besar dari pada molekul air, misalnya molekul garam dan lainnya, akan terpisah dan akan ikut ke dalam air buangan.

Dalam pengoperasian penyaringan skala molekul ini diinjeksi 3 jenis bahan kimia, yaitu anti scalant (anti pengerakan), anti biofouling (anti penyumbatan karena unsur biologis) dan bahan pengawet yang berfungsi untuk mengawetkan membran yang berupa Thin Composite Film, bahan kimia tersebut tersaring dan akan keluar bersama dengan air buangan.

Air baku yang diambil dari sumur setempat tidak memenuhi persyaratan untuk air minum karena kandungan garam mencapai 12.000 ppm dan parameter lainnya juga melebihi ambang batas (Tabel 5). Setelah melalui proses pengolahan pendahuluan dan lanjutan air hasil olahan mempunyai kualitas sebagai air siap minum (Tabel 6), yaitu memenuhi standar kualitas air minum yang disyaratkan oleh Departemen Kesehatan RI. Kandungan jumlah padatan terlarut umumnya lebih kecil dari 150 ppm (mg per liter).

\section{ANALISA EKONOMI}

Untuk membangun satu unit instalasi pengolahan air asin dengan sistem reverse osmosis kapasitas 10.000 liter/hari ini diperlukan biaya sebesar 200.000.000 rupiah. Biaya operasional dan pemeliharaan alat termasuk honor pegawai setiap bulannya seperti terlihat pada Tabel 8. adalah sekitar Rp.2.36.100 . Biaya produksi air perliternya adalah Rp. 6,8. Apabila air olahan tersebut dijual dengan sistem kemasan botol galon, maka biaya total produksi air perbotol galonnya adalah Rp. 290. Dari Tabel 9 analisa pendapatan dan keuntungan hasil penjualan air, terlihat bahwa apabila air tersebut dijual dengan harga minimal Rp. 2.500,00/botol galon (harga pasaran air kemasan botol galon komersil sekitar Rp. 10.000,00) dan bila air dapat terjual $50 \%$ saja atau 85 botol galon/perhari, maka diperoleh pendapatan setiap bulan sebesar Rp. 6.375.000,00. Pendapatan ini setelah dipotong biaya pengeluaran perbulan maka diperoleh keuntungan hasil penjualan air hasil olahan setiap bulannya sebesar Rp. 5.635.500,00, dengan demikian diperkirakan investasi alat kembali pada tahun ketiga. Dengan asumsi air hasil olahan terjual $75 \%$ biaya investasi alat diharapkan akan kembali pada tahun ke dua.

\section{PENUTUP}

Aplikasi teknologi pengolahan air asin menjadi air siap minum dengan sistem reverse osmosis ini mampu memproduksi air siap minum $10 \mathrm{~m}^{3}$ per hari (8jam pengoprerasian/hari). proses pengolahan dibagi menjadi 2 (dua) bagian utama, yaitu unit pengolahan pendahuluan (Pretreatment) dan unit pengolahan lanjutan (Treatment).

Manfaat secara langsung aplikasi teknologi pengolahan air asin sistem reverse osmosis terhadap masyarakat setempat adalah memperoleh air minum yang sehat dan memenuhi persyaratan sebagai air minum dengan harga yang jauh lebih murah dari pada air minum dalam kemasan (air mineral yang dijual secara komersil). Air hasil pengolahan ini langsung dapat diminum tanpa perlu dimasak terlebih dahulu, dengan biaya pengolahan per liter air minum dari air baku adalah Rp. 6,8dimana air minum dalam kemasan saat ini mencapai Rp. 2.000 per liter.

Manfaat secara tidak langsung penerapan aplikasi teknologi pengolahan air asin sistem reverse osmosis ini adalah merupakan unit percontohan penerapan teknologi tinggi yang dikemas sangat sederhana sehingga dapat dan mudah diterapkan pada daerah lain.

Manfaat secara umum adalah adanya peningkatan taraf kehidupan masyarakat, karena dengan mengkonsumsi air yang sehat dan bersih berarti masyarakat juga terhindar dari kemungkinan menderita sakit (muntaber, disentri atau thypus) dan dengan demikian kesejahteraan masyarakat juga semakin meningkat.

\section{DAFTAR PUSTAKA}

1. Benefiled, L.D., Judkins, J.F., and Weand, B.L., "Process Chemistry For Water And Waste Treatment", Prentice-Hall, Inc., Englewood, 1982

2. Bunce, N.J. , 1993, Intruduction to Environmental Chemistry, Wuerz Publishing Ltd, Winnipeg, Canada.

3. Fair, G.M., Geyer, J.C., AND Okun, D.A., " Element Of Water Supply And Waste Water Disposal ", Second Edition, John Wiley And Sons, New York, 1971

4. Hamer, M. J., " Water And Waste water Technology ", Second Edition, John Wiley And Sons, New York, 1986 
5. Nusa, I.D., Arie, H., Nugro, R., dan Haryoto, I., 1996, Studi Kelayakan Teknis dan Ekonomis Unit Pengolah Air Sistem Reverse Osmosis Kapasitas 500 m3/hari Untuk perusahaan minyak lepas pantai, P.T. Paramita Binasarana, Jakarta.

6. Peavy, H.S., Rowe, D.R, AND Tchobanoglous, S.G., "Environmental Engineering ", Mc Graw-Hill Book Company, Singapore, 1986
7. Sasakura, 1995, Desalination Technology and Its Aplication, P.T. Sasakura Indonesia, Jakarta.

8. Tatsumi Iwao, "Water Work Engineering (JOSUI KOGAKU) ", Japanese Edition, Tokyo, 1971

9. Viessman W,JR., "Water Supply And Pollution Control ", fourth edition, Harper and Ror Publisher, New york, 1985.

\section{LAMPIRAN}

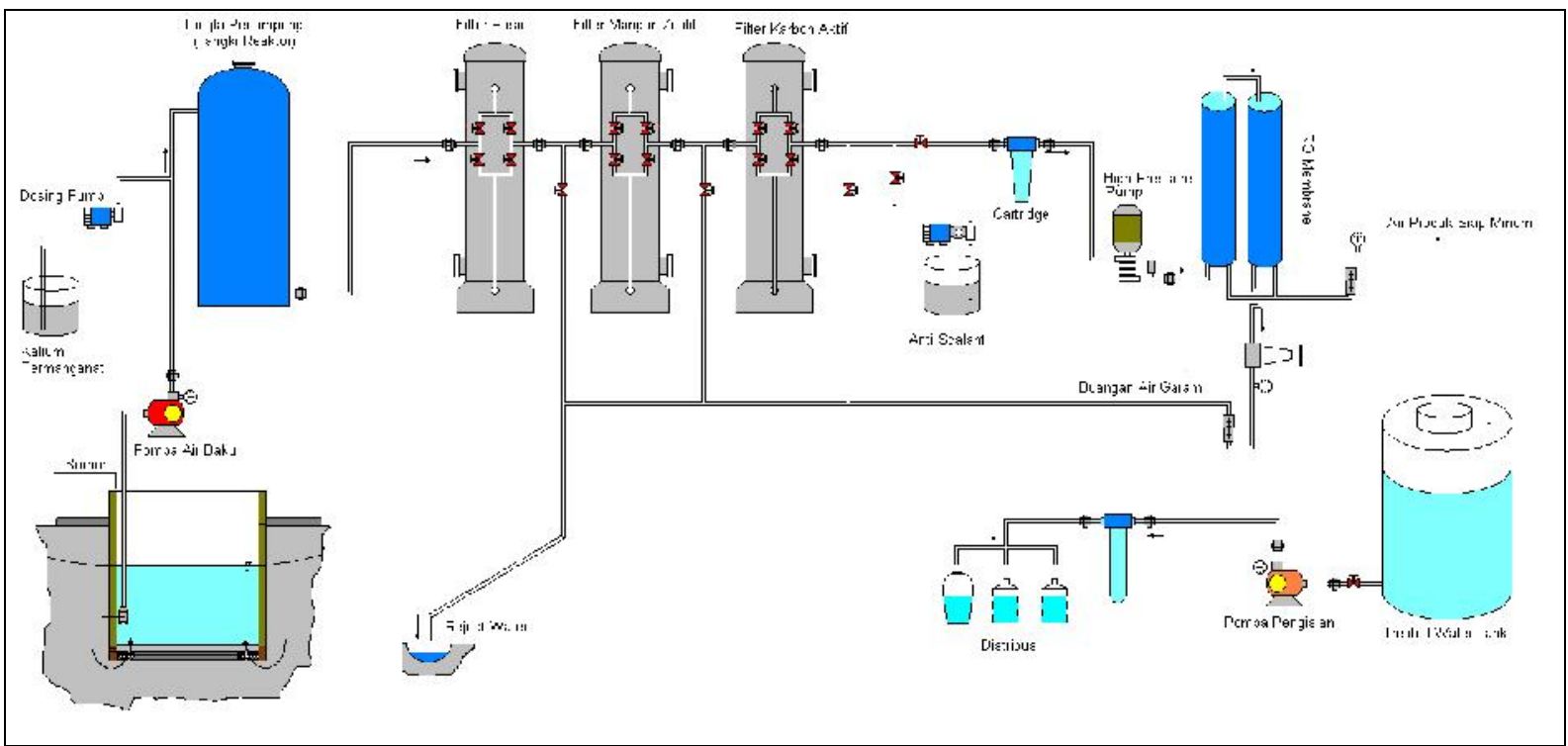

Gambar 15 : Diagram alir pengolah air Asin sistem reverse osmosis.

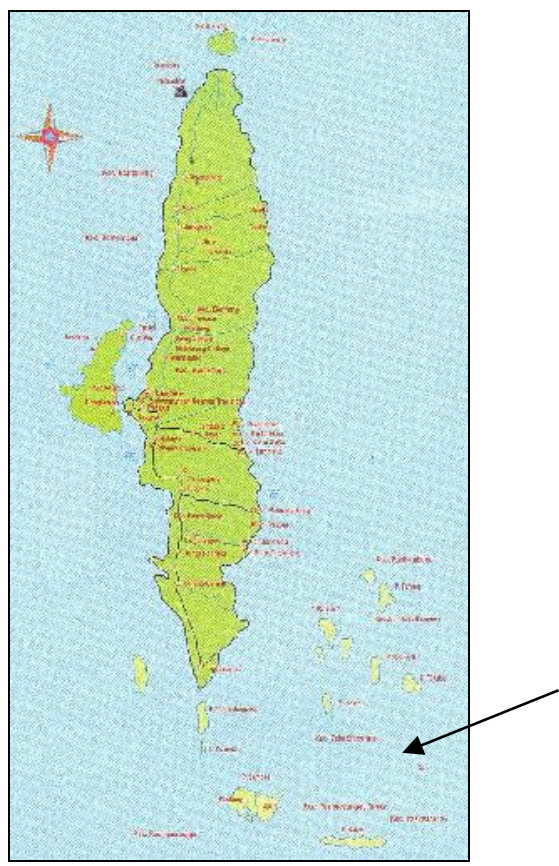

Gambar 16 : Lokasi Unit IPA-RO di Desa Tarupa. 


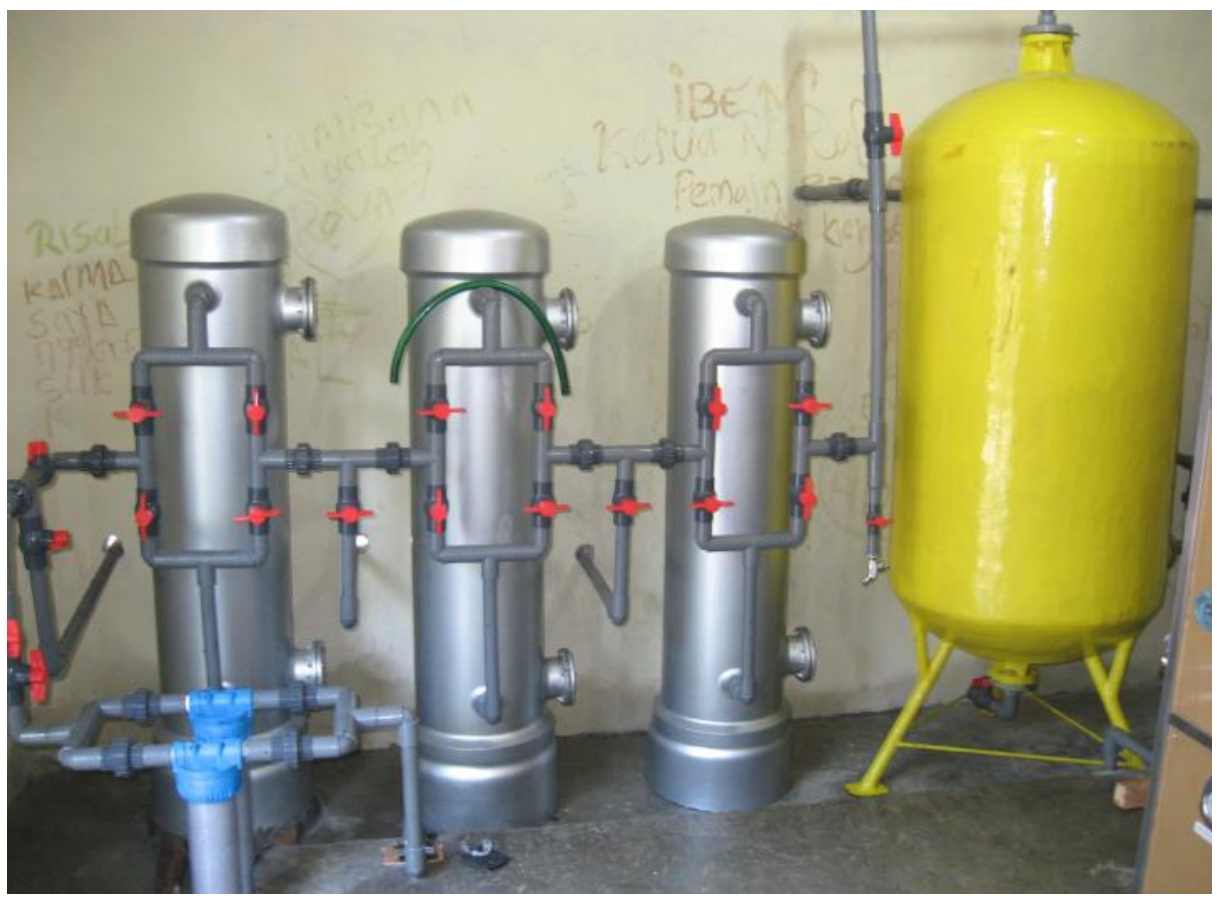

Gambar 17 : Unit Pretreatment.

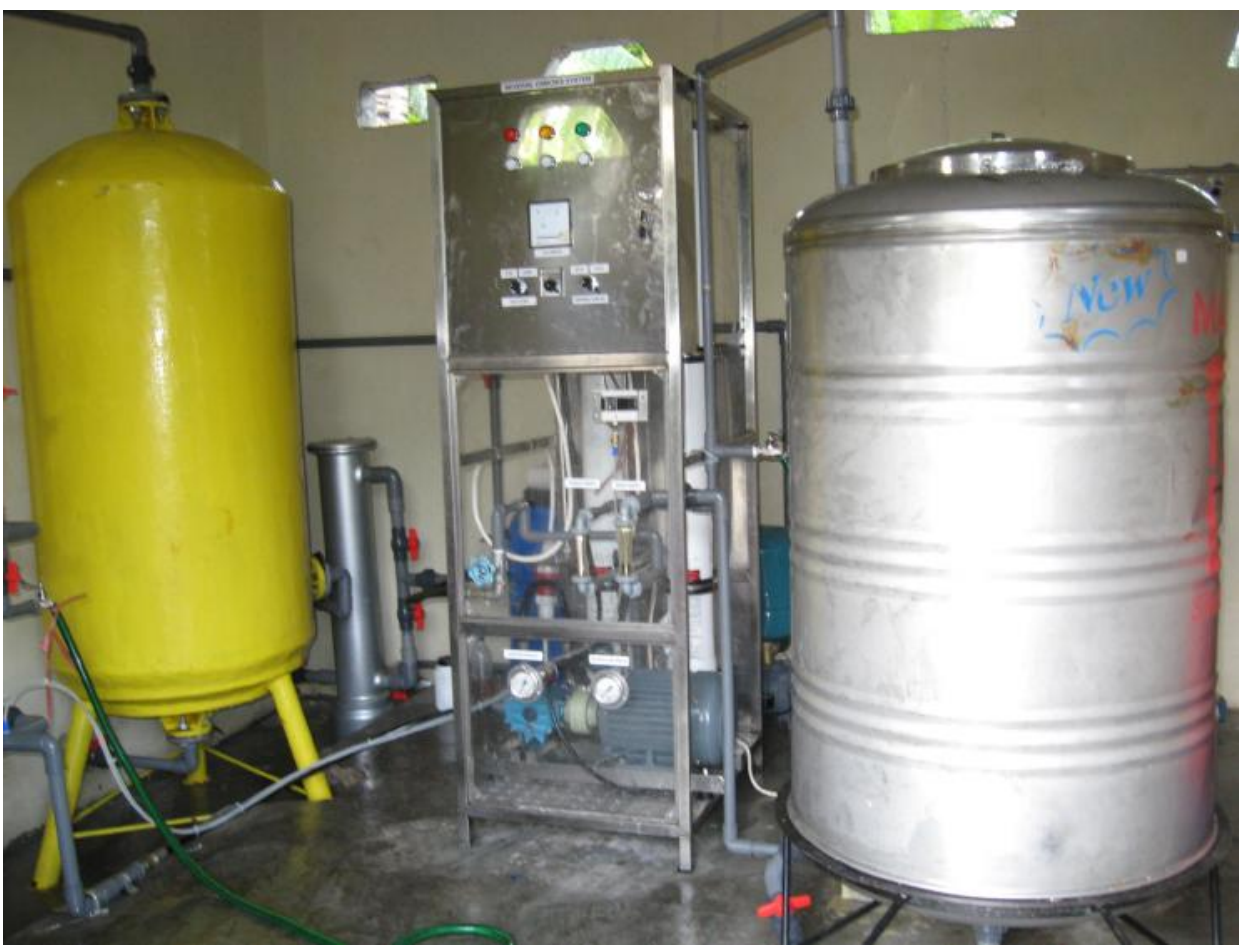

Gambar 18 : Unit Treatment Reverse Osmosis.

Tabel 3 : Kualitas Air Baku. 


\begin{tabular}{|r|l|c|c|}
\hline No & \multicolumn{1}{|c|}{ PARAMETER } & SATUAN & Hasil Analisa \\
\hline \hline 1 & Warna & Skala TCU & 70 \\
\hline 2 & Bau & - & Tak berbau \\
\hline 3 & Rasa & - & Asin \\
\hline 4 & Kekeruhan & NTU & 1,1 \\
\hline 5 & Suhu & $\mathrm{o}$ & - \\
\hline 6 & Jumlah zat padat terlarut (TDS)* ${ }^{*}$ & 12.000 \\
\hline 7 & Zat organik (KMNO4) & $\mathrm{mg} / \mathrm{l}$ & 60 \\
\hline 8 & Derajad keasaman (pH) & - & 7,8 \\
\hline 9 & Kesadahan jumlah (CaCO3) & $\mathrm{mg} / \mathrm{l}$ & 430 \\
\hline 10 & Besi (Fe) & $\mathrm{mg} / \mathrm{l}$ & 0,2 \\
\hline 11 & Mangan (Mn) & $\mathrm{mg} / \mathrm{l}$ & 0,1 \\
\hline 12 & Sulfat $(\mathrm{SO} 4)$ & $\mathrm{mg} / \mathrm{l}$ & 3 \\
\hline 13 & Nitrit (sbg-N) & $\mathrm{mg} / \mathrm{l}$ & 0,3 \\
\hline 14 & Klorida & $\mathrm{mg} / \mathrm{l}$ & 0,2 \\
\hline 15 & Seng $(\mathrm{Zn})$ & $\mathrm{mg} / \mathrm{l}$ & - \\
\hline 16 & Kromium $(\mathrm{Cr})$ & $\mathrm{mg} / \mathrm{l}$ & - \\
\hline 17 & Timbal $(\mathrm{Pb})$ & $\mathrm{mg} / \mathrm{l}$ & - \\
\hline 18 & Sisa Chlor & $\mathrm{mg} / \mathrm{l}$ & - \\
\hline
\end{tabular}

Sumber : Hasil Analisa PDAM, Agustus 2007

Tabel 4 : Kualitas Air Hasil Pengolahan.

\begin{tabular}{|c|l|c|c|c|}
\hline No. & \multicolumn{1}{|c|}{ PARAMETER } & SATUAN & Standar air bersih & Hasil Analisa \\
\hline 1 & Warna & Skala TCU & 50 & 10 \\
\hline 2 & Bau & - & Tak berbau & Tak berbau \\
\hline 3 & Rasa & - & Tak berasa & Tak berasa \\
\hline 4 & Kekeruhan & NTU & 25 & 0,3 \\
\hline 5 & Suhu & ${ }^{\circ} \mathrm{C}$ & Suhu udara +3 & - \\
\hline 6 & Jumlah zat padat terlarut (TDS) & $\mathrm{mg} / \mathrm{l}$ & 1500 & 130,0 \\
\hline 7 & Zat organik (KMNO4) & $\mathrm{mg} / \mathrm{l}$ & 10 & 3,4 \\
\hline 8 & Derajad keasaman (pH) & - & $6,5-9,0$ & 7 \\
\hline 9 & Kesadahan jumlah (CaCO3) & $\mathrm{mg} / \mathrm{l}$ & 500 & 42 \\
\hline 10 & Besi (Fe) & $\mathrm{mg} / \mathrm{l}$ & 1,0 & 0,001 \\
\hline 11 & Mangan (Mn) & $\mathrm{mg} / \mathrm{l}$ & 0,5 & 0,02 \\
\hline 12 & Sulfat $(\mathrm{SO} 4)$ & $\mathrm{mg} / \mathrm{l}$ & 400 & 2 \\
\hline 13 & Nitrit $(\mathrm{sbg}-\mathrm{N})$ & $\mathrm{mg} / \mathrm{l}$ & 1,0 & 0,01 \\
\hline 14 & Klorida & $\mathrm{mg} / \mathrm{l}$ & 600 & 36 \\
\hline 15 & Seng (Zn) & $\mathrm{mg} / \mathrm{l}$ & 5,0 & - \\
\hline 16 & Kromium $(\mathrm{Cr})$ & $\mathrm{mg} / \mathrm{l}$ & 0,05 & - \\
\hline 17 & Timbal $(\mathrm{Pb})$ & $\mathrm{mg} / \mathrm{l}$ & 0,05 & - \\
\hline 18 & Sisa Chlor & $\mathrm{mg} / \mathrm{l}$ & - & - \\
\hline$P D A M$ & Agustus 2007 & & \\
\hline
\end{tabular}


Tabel 5 : Komponen Unit Pengolahan Pendahuluan (Pretreatment).

\begin{tabular}{|c|c|c|c|c|}
\hline No & Nama Barang & \multicolumn{2}{|r|}{ Spesifikasi } & Keterangan \\
\hline 1 & 2 & & 3 & 4 \\
\hline 1 & $\begin{array}{l}\text { Pompa Air Baku } \\
\text { (untuk pretreatment) }\end{array}$ & $\begin{array}{l}\text { Tipe } \\
\text { Kapasitas } \\
\text { Daya } \\
\text { Tekanan } \\
\text { Daya hisap } \\
\text { Daya dorong } \\
\text { Material } \\
\text { Jumlah }\end{array}$ & $\begin{array}{l}: \text { Sentrifugal } \\
: \text { 26 l/min } \\
: \text { 250-500 Watt/220 V } \\
: 4-7 \text { bar } \\
: \quad 9 \mathrm{~m} \\
: \quad 40 \mathrm{~m} \\
: \quad \text { Stainless steel } \\
: \quad 1 \text { buah }\end{array}$ & $\begin{array}{l}\text { Suplai air baku } \\
\text { bertekanan }\end{array}$ \\
\hline 2 & Static Mixer & $\begin{array}{l}\text { Tipe } \\
\text { Kapasitas } \\
\text { Tekanan } \\
\text { Material } \\
\text { Jumlah }\end{array}$ & $\begin{array}{l}: \text { Cross flow, } \\
: \quad 30 \text { liter/menit } \\
: \quad \text { Max } 7 \text { bar } \\
: \text { PVC 6" x } 100 \mathrm{Cm} \\
: \quad 1 \text { buah }\end{array}$ & Hydraulic mixing \\
\hline 3 & $\begin{array}{l}\text { Pompa Dosing } \\
\text { (Tunggal/Single Acting) }\end{array}$ & $\begin{array}{l}\text { Tipe } \\
\text { Kapasitas } \\
\text { Daya } \\
\text { Tekanan } \\
\text { Pump head } \\
\text { Diaphragm } \\
\text { Jumlah }\end{array}$ & $\begin{array}{l}\text { Chemtech } 100 / 030 \\
: \text { 4.7 It/hour } \\
: \text { 125 Watt/220 V } \\
: \text { Bars } \\
: \text { SAN } \\
\vdots \text { Hypalon } \\
: \text { buah }\end{array}$ & $\begin{array}{l}\text { Untuk injeksi } \\
\mathrm{KmnO}_{4}\end{array}$ \\
\hline 4 & Tangki Bahan Kimia & $\begin{array}{l}\text { Tipe } \\
\text { Kapasitas } \\
\text { Bahan }\end{array}$ & $\begin{array}{ll}: & \text { Drum } \\
: & 50 \text { liter } \\
: & \text { FRP }\end{array}$ & $\begin{array}{l}\text { Penampungan } \\
\text { larutan } \mathrm{KmnO}_{4}\end{array}$ \\
\hline 5 & Tangki Reaktor & $\begin{array}{l}\text { Tipe } \\
\text { Kapasitas } \\
\text { Bahan } \\
\text { Ukuran } \\
\text { Tekanan } \\
\text { Material } \\
\text { Jumlah }\end{array}$ & $\begin{array}{ll}: & \text { Preesure tank } \\
: & 1-1,5 \mathrm{~m}^{3} / \mathrm{Jam} \\
: & \text { FRP } \\
: & \phi 73 \mathrm{Cm} \times \text { tinggi } 120 \mathrm{~cm} \\
: & \text { Max } 7 \text { bar } \\
: & \text { FRP } \\
: & 1 \text { buah }\end{array}$ & $\begin{array}{l}\text { Terjadinya reaksi } \\
\text { oksidasi }\end{array}$ \\
\hline 6 & Saringan Pasir Cepat & $\begin{array}{l}\text { Tipe } \\
\text { Kapasitas } \\
\text { Bahan } \\
\text { Ukuran } \\
\text { Tekanan } \\
\text { Pipa Inlet / outlet } \\
\text { System } \\
\text { Media Filter } \\
\text { Media Penahan } \\
\text { Material } \\
\text { Jumlah }\end{array}$ & $\begin{array}{ll}: & \text { Tabung Silinder } \\
: & 0,5-1,8 \mathrm{M}^{3} / \text { Jam } \\
: & \text { FRP } \\
: & \phi 12 \text { “, tinggi } 120 \mathrm{~cm} \\
: & \text { Max } 7 \text { bar } \\
: & 1 \text { inch } \\
: & \text { manual } \\
: & \text { Pasir Silika } \\
: & \text { Gravel } \\
: & \text { PVC } \\
: & 1 \text { buah }\end{array}$ & $\begin{array}{l}\text { Pemisahan } \\
\text { Oksida Fe, Mn \& } \\
\text { logam val II }\end{array}$ \\
\hline 7 & Saringan Mangan Zeolit & $\begin{array}{l}\text { Tipe } \\
\text { Kapasitas } \\
\text { Bahan } \\
\text { Ukuran } \\
\text { Tekanan } \\
\text { Pipa Inlet / outlet } \\
\text { System } \\
\text { Media Filter } \\
\text { Media Penahan } \\
\text { Material } \\
\text { Jumlah }\end{array}$ & $\begin{array}{ll}: & \text { Tabung Silinder } \\
: & 0,5-1,8 \mathrm{M}^{3} / \mathrm{Jam} \\
: & \text { FRP } \\
: & \phi 12 \text { “, tinggi } 120 \mathrm{~cm} \\
: & \text { Max } 7 \text { bar } \\
: & 1 \text { inch } \\
: & \text { manual } \\
: & \text { Mangani zeolit } \\
: & \text { Gravel } \\
: & \text { PVC } \\
: & 1 \text { buah }\end{array}$ & $\begin{array}{l}\text { Pengambilan } \\
\text { Fe, Mn \& logam } \\
\text { val II sisa }\end{array}$ \\
\hline
\end{tabular}




\begin{tabular}{|c|c|c|c|c|}
\hline 8 & Saringan Carbon Aktif & $\begin{array}{l}\text { Tipe } \\
\text { Kapasitas } \\
\text { Bahan } \\
\text { Ukuran } \\
\text { Tekanan } \\
\text { Pipa Inlet / outlet } \\
\text { System } \\
\text { Media Filter } \\
\text { Material } \\
\text { Media Penahan }\end{array}$ & $\begin{array}{ll}: & \text { Tabung Silinder } \\
: & 0,5-1,8 \mathrm{M}^{3} / \mathrm{Jam} \\
: & \text { FRP } \\
: & \phi 12 \text { “, tinggi } 120 \mathrm{~cm} \\
: & \text { Max } 7 \text { bar } \\
: & 1 \text { inch } \\
\vdots & \text { manual } \\
\vdots & \text { Karbon Aktif } \\
: & \text { PVC } \\
: & \text { Gravel }\end{array}$ & $\begin{array}{l}\text { Adsorbsi warna \& } \\
\text { bau }\end{array}$ \\
\hline 9 & Cartridge Filter & $\begin{array}{l}\text { Tipe } \\
\text { Kapasitas } \\
\text { Bahan } \\
\text { Ukuran } \\
\text { Tekanan } \\
\text { Pipa Inlet / outlet } \\
\text { Media Filter } \\
\text { Ukuran media } \\
\text { Jumlah }\end{array}$ & $\begin{array}{ll}: & \text { Tabung Silinder } \\
: & 0,5-1,8 \mathrm{M}^{3} / \mathrm{Jam} \\
: & \text { Plastic } \\
: & \phi 15 \mathrm{~cm} \text {, tinggi } 60 \mathrm{~cm} \\
: & \text { Max } 7 \text { bar } \\
: & 1 \text { inch } \\
: & \text { nylon } \\
: & 0,1 \text { micron } \\
: & 1 \text { buah }\end{array}$ & $\begin{array}{l}\text { Pemisahan } \\
\text { partikel }\end{array}$ \\
\hline
\end{tabular}

Tabel 6 : Komponen Unit Pengolahan Lanjutan (Reverse Osmosis).

\begin{tabular}{|c|c|c|c|c|}
\hline No & Nama Barang & & Spesifikasi & Keterangan \\
\hline 1 & Unit Reverse Osmosis & $\begin{array}{l}\text { Tipe } \\
\text { Kapasitas } \\
\text { Material } \\
\text { Tekanan umpan } \\
\text { Tekanan operasi } \\
\text { Suhu operasi } \\
\text { ToleransiTDS } \\
\text { Toleransi Fe } \\
\text { Toleransi Mn } \\
\text { Toleransi Cl } \\
\text { Type elemen } \\
\text { Jumlah elemen } \\
\text { Ukuran elemen } \\
\text { Motor } \\
\text { Kelengkapan }\end{array}$ & $\begin{array}{ll}: & \text { SW } 10 \mathrm{~T} \\
: & 10 \mathrm{~m}^{3} / \text { hari } \\
: & \text { Stainless Steel } \\
: & \text { Minimum } 1 \mathrm{bar} \\
\vdots & 20-100 \mathrm{bars} \\
: & \text { Max } 40{ }^{\circ} \mathrm{C} \\
: & <40000 \mathrm{ppm} \\
: & \text { Max } 0.01 \mathrm{ppm} \\
\vdots & \text { Max } 0.01 \mathrm{ppm} \\
: & \text { Max } 0.01 \mathrm{ppm} \\
: & \text { Thin Film Composite } \\
; & 2 \text { buah } \\
: & 4 \times 20 \text { inch } \\
: & 2,2 \mathrm{KW} ; 380 \text { Volt; } 50 \mathrm{~Hz} ; \\
& 2900 \text { RPM } \\
: & \text { Product Flow meter } \\
& \text { Reject flow meter } \\
& \text { Inlet presure gauge } \\
& \text { Operating presure gauge } \\
& \text { Pre filter pressure gauge } \\
& \text { Reject pressure regulator } \\
\text { Solenoid valve } \\
\text { Conductivity tester } \\
\text { Tool Kit } \\
\text { Anti Soalan Unit } \\
\text { Anti Fouling Unit }\end{array}$ & $\begin{array}{l}\text { Desalinasi } \\
\text { osmosa balik }\end{array}$ \\
\hline
\end{tabular}


Tabel 7 : Unit Pengisian \& Power.

\begin{tabular}{|c|c|c|c|c|}
\hline No & Nama Barang & \multicolumn{2}{|r|}{ Spesifikasi } & Keterangan \\
\hline 1 & $\begin{array}{l}\text { Tangki penampung air } \\
\text { olahan }\end{array}$ & $\begin{array}{l}\text { Tipe } \\
\text { Kapasitas } \\
\text { Bahan } \\
\text { Jumlah }\end{array}$ & $\begin{array}{ll}: & \text { Drum } \\
: & 500 \text { liter } \\
: & \text { Stainless Steel } \\
: & 2 \text { buah }\end{array}$ & $\begin{array}{l}\text { Tempat } \\
\text { penyimpanan } \\
\text { sementara } \\
\text { air olahan }\end{array}$ \\
\hline 2 & Pompa air pengisian & $\begin{array}{l}\text { Tipe } \\
\text { Kapasitas } \\
\text { Daya } \\
\text { Tekanan } \\
\text { Daya hisap } \\
\text { Daya dorong } \\
\text { Material } \\
\text { Jumlah }\end{array}$ & 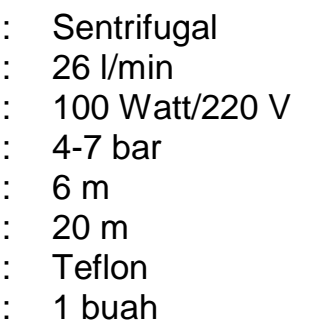 & Suplai air olahan \\
\hline 3 & Ultraviolet & $\begin{array}{l}\text { Tipe } \\
\text { Kapasitas } \\
\text { Bahan } \\
\text { Ukuran } \\
\text { Tekanan } \\
\text { Pipa Inlet / outlet } \\
\text { Daya } \\
\text { Jumlah }\end{array}$ & 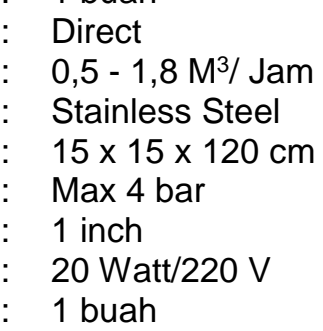 & $\begin{array}{l}\text { Pemisahan } \\
\text { partikel }\end{array}$ \\
\hline 4 & Generator Set & $\begin{array}{l}\text { Tipe } \\
\text { Kapasitas } \\
\text { Bahan } \\
\text { Ukuran } \\
\text { Daya } \\
\text { Jumlah }\end{array}$ & $\begin{array}{ll}: & \text { TF } 155 \mathrm{R} \\
: & 23 \mathrm{PK} \\
: & \text { Steel } \\
: & 60 \times 60 \times 150 \mathrm{~cm} \\
: & 10 \mathrm{KVA} / 380 \mathrm{~V} \\
& 1 \text { buah }\end{array}$ & Supply Power \\
\hline
\end{tabular}

Tabel 8: Biaya pemeliharaan dan produksi pengolahan air asin sistem Reverse Osmosis

\section{Biaya pemeliharaan :}

\begin{tabular}{|c|c|c|c|c|c|}
\hline 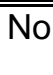 & Komponen Pembiayaan & \multicolumn{2}{|c|}{ Jumlah } & "Harga & "Harga $\mathrm{Rp}$ \\
\hline 1 & Bahan Bakar (solar) & 240 & Liter & 4,500 & $1,080,000$ \\
\hline 2 & Bahan kimia $\mathrm{KMnO} 4$ & 0.05 & $\mathrm{~kg}$ & 20,000 & 1,000 \\
\hline 3 & Anti scalling & 0.01 & $\mathrm{~kg}$ & 40,000 & 400 \\
\hline 4 & Anti biofoaling & 0.01 & $\mathrm{~kg}$ & 40,000 & 400 \\
\hline 5 & Pengawet membran & 0.01 & $\mathrm{~kg}$ & 30,000 & 300 \\
\hline 6 & Media saringan manganese zeolit & 1 & $\mathrm{~kg}$ & 24,000 & 24,000 \\
\hline 7 & Media saringan karbon aktif & 1 & $\mathrm{~kg}$ & 30,000 & 30,000 \\
\hline 8 & Tenaga Kerja & 2 & orang & 400,000 & 800,000 \\
\hline 9 & Pemeliharaan & & bulan & 100,000 & 100,000 \\
\hline & \multicolumn{4}{|l|}{ Total Pembiayaan Per Bulan } & $2,036,100$ \\
\hline
\end{tabular}




\section{Biaya Produksi :}

\begin{tabular}{|c|c|c|c|c|c|}
\hline No & Keterangan & Kapasitas & Satuan & $\begin{array}{l}\text { Volume/ } \\
\text { Waktu }\end{array}$ & $\begin{array}{c}\text { Harga } \\
\text { Rp }\end{array}$ \\
\hline 1 & Kapasitas Maksimum Produksi & 10 & m3/hari & & \\
\hline 2 & Kapasitas Produksi $\left(8\right.$ jam, $\left.\mathrm{m}^{3}\right)$ & 3.33 & m3/jam & 8 & \\
\hline 3 & Biaya Produksi Air (Rupiah/liter) & & Rp/liter & & 6.8 \\
\hline 4 & Jumlah Produksi (Botol Gallon/hari) & 171 & galon/hr & 19.5 & \\
\hline 5 & Biaya Produksi Air / Botol Gallon & & Rp/Botol & & 132.6 \\
\hline 6 & Biaya Segel Botol & & rupiah & & 150 \\
\hline & Biaya Produksi /Botol Gallon & & & & 289.4 \\
\hline
\end{tabular}

Tabel 9 : Harga Jual dan Asumsi Keuntungan Tiap Bulan.

\begin{tabular}{||l|l|l|l|r|r|r||}
\hline \hline No & $\begin{array}{l}\text { Pendapatan Maksimal dengan } \\
\text { Operasi 8 jam }\end{array}$ & & & $\begin{array}{c}\text { Asumsi 1 } \\
\text { Rp }\end{array}$ & $\begin{array}{c}\text { Asumsi 2 } \\
\text { Rp }\end{array}$ & \multicolumn{1}{|c|}{$\begin{array}{c}\text { Asumsi 3 } \\
\text { Rp }\end{array}$} \\
\hline \hline 1 & Kapasitas Produksi (8 jam/hari) & Gallon/bulan & 5,130 & & & \\
2 & Harga Jual Produk (asumsi) & Rupiah & & 1,500 & 2,000 & 2,500 \\
3 & Pendapatan Maksimal & Rupiah & & $7,695,000$ & $10,260,000$ & $12,825,000$ \\
\hline \hline
\end{tabular}

\begin{tabular}{|c|c|c|c|c|c|c|}
\hline No & $\begin{array}{c}\text { Pendapatan Operasi } 8 \\
\text { jam/Bulan }\end{array}$ & $\begin{array}{c}\text { Gallon/ } \\
\text { hari }\end{array}$ & $\begin{array}{l}\text { Terjual } \\
\text { Persent }\end{array}$ & $\begin{array}{c}\text { Asumsi } 1 \\
\mathrm{Rp}\end{array}$ & $\begin{array}{c}\text { Asumsi } 2 \\
\text { Rp }\end{array}$ & $\begin{array}{c}\text { Asumsi } 3 \\
\text { Rp }\end{array}$ \\
\hline 1 & Asumsi Terjual $100 \%$ & 171 & $100,00 \%$ & 7,695,000 & 10,260,000 & "12,825,000 \\
\hline 2 & Asumsi Terjual $75 \%$ & 128 & $75,00 \%$ & $5,760,000$ & $7,680,000$ & $9,600,000$ \\
\hline 3 & Asumsi Terjual $50 \%$ & 85 & $50,00 \%$ & 3,8 &, 000 & 5,000 \\
\hline 4 & Asumsi Terjual $25 \%$ & 43 & $25,00 \%$ & $1,935,000$ & $2,580,000$ & $3,225,000$ \\
\hline 5 & Asumsi 1 Terjual Minimal & 41 & $23,40 \%$ & $1,845,000$ & $2,460,000$ & $3,075,000$ \\
\hline 6 & Asumsi 2 Terjual Minimal & 31 & $18,14 \%$ & & $1,860,000$ & $2,325,000$ \\
\hline 7 & Asumsi 3 Terjual Minimal & 25 & $14,63 \%$ & & & $1,875,000$ \\
\hline
\end{tabular}

\begin{tabular}{|c|c|c|c|c|c|c|}
\hline No & $\begin{array}{l}\text { Keuntungan Tiap Bulan } \\
\text { (Rp) }\end{array}$ & $\begin{array}{c}\text { Gallon/ } \\
\text { hari }\end{array}$ & $\begin{array}{l}\text { Terjual } \\
\text { Persent }\end{array}$ & $\begin{array}{l}\text { Asumsi } 1 \\
\text { Rp }\end{array}$ & $\begin{array}{c}\text { Asumsi } 2 \\
\text { Rp }\end{array}$ & $\begin{array}{c}\text { Asumsi } 3 \\
\text { Rp }\end{array}$ \\
\hline 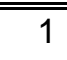 & 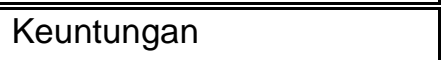 & 171 & $\overline{100,00} \%$ & (6,207,300 & $8,8,772,300$ & $1011,337,300$ \\
\hline 2 & Keuntungan & 128 & $75,00 \%$ & $4,646,400$ & $6,566,400$ & $8,486,400$ \\
\hline 3 & Keuntungan & 85 & $50,00 \%$ & $3,085,500$ & $4,360,500$ & $5,635,500$ \\
\hline 4 & Keuntungan & 43 & $25,00 \%$ & $1,560,900$ & $2,205,900$ & $2,850,900$ \\
\hline 5 & Keuntungan Min (asumsi 1) & 41 & $23,40 \%$ & $1,488,300$ & $2,103,300$ & $2,718,300$ \\
\hline 6 & Keuntungan Min (asumsi 2) & 31 & $18,14 \%$ & & $1,590,300$ & $2,055,300$ \\
\hline 7 & Keuntungan Min (asumsi 3) & 25 & $14,63 \%$ & & & $1,657,500$ \\
\hline
\end{tabular}

